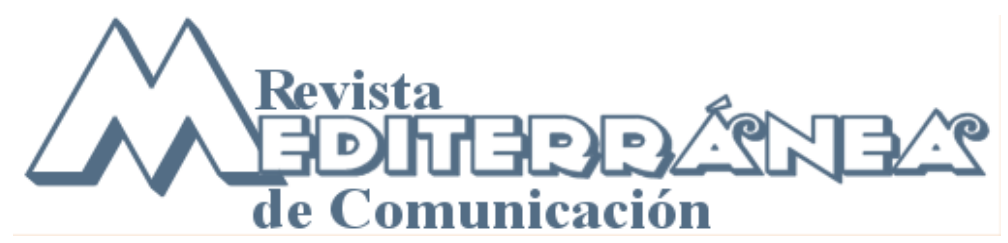

\title{
La imagen de Venezuela en la prensa española. Una visión desde los diarios: EI País, El Mundo, ABC y La Vanguardia
}

\author{
Venezuela's image in the Spanish press. \\ A view from the newspapers: \\ EI Pais, EI Mundo, ABC and La Vanguardia
}

Marianela Urdaneta García

Profesora de la Universidad Universidad Bolivariana de Venezuela.

haydee2007@hotmail.com

\section{Resumen}

La presente investigación tiene como objetivo analizar el tratamiento periodístico que los diarios EI País, El Mundo, ABC y La Vanguardia hacen sobre Venezuela para difundir y proyectar su imagen. Se utilizó el análisis de contenido sustentado en autores como: McCarteney, Butler y Bennett, (2008); González, (2008); Noya y col., (2007); Igartua y Humanes, (2004); Dhoest, (2004); Martínez y Díaz, (2003); Bodas y Gragoevic, (1994); entre otros. Como conclusión se obtuvo que los tres principales temas con los que se vinculó a Venezuela fueron la situación interna del país a causa de su sistema de gobierno $(31,2 \%)$, la relación con los países latinoamericanos no miembros del ALBA (21,6\%), relación con los países miembros del ALBA $(19,7 \%)$. Hubo un predominio de la noticia como género periodístico $(58,7 \%)$, no obstante se observó que en el $53,9 \%$ de las noticias publicadas el redactor hacía juicios de valores y que el $56 \%$ de las noticias difundidas tienen entre cero y una fuente, lo cual permite señalar que las informaciones publicadas son escuetas y sin profundidad periodística. En cuanto al tratamiento que se le dio a las informaciones difundidas sobre Venezuela se precisó que el $81,7 \%$ tuvieron una cobertura negativa y sólo en un $2,8 \%$ hubo un enfoque positivo.

\section{Palabras claves}

República Bolivariana de Venezuela, imagen de país, imagen de marca país, prensa, España, Presidente Hugo Chávez, análisis de contenido.

\section{Abstract}

This research aims to study the various jobs that have been made about the construction of the country's image and branding country and then analyze the press coverage that the newspapers EI Pais, El Mundo, ABC and La Vanguardia made on Venezuela to disseminate and project its image. It uses the content analysis supported by authors such as: Mccarteney, Butler and 
Bennett, (2008); González, (2008); Noya and col., (2007); Igartúa and Humanes, (2004); Dhoest, (2004); Martínez and Díaz, (2003); Bodas and Gragoevic, (1994), among others. As a conclusion was reached that the three major issues wich were linked to Venezuela the internal situation of the country due to the established system of government $(31,2 \%)$, its relations with the Latin American countries that are not part of the ALBA bloc $(21,6 \%)$, and with those belonging to ALBA bloc (19,7\%). There has been a preponderance of the news as part of the journalistic genre $(58,7 \%)$. Moreover, it was noticeable that $53,9 \%$ of the news written by the editor border on value judgments and that $56 \%$ of the news they release originate from a range of zero and one source, which allows us to point out that the information they put across lacks substance and professional depth. In regard to how they process the released information on Venezuela, it was specified that $81,7 \%$ of the news coverage was managed in a negative fashion and only $2,8 \%$ of them was detailed in a positive mode.

\section{Key Words}

Bolivarian Republic of Venezuela, country image, country brand image, media, Spain, President Hugo Chávez, analysis of contents.

Sumario: 1. Introducción. 2. Objetivo. 3. Aspecto teórico. 3.1 La imagen de país e imagen de marca país. 3.1.1 Construcción de la "imagen país". 4. Metodología aplicada y corpus. 5. Resultados. 5.1 Temas publicados sobre Venezuela. 5.2 Géneros periodísticos. 5.3 Tratamiento o tendencia de las publicaciones. 5.4 Las fuentes informativas. 5.5 Los autores de las informaciones publicadas. 6. Conclusiones. 7. Bibliografía. 8. Notas.

Summary: 1. Introduction. 2. Objective. 3. Theoretical aspects. 3.1. The country's image and brand country. 3.1.1 Construction of the "national image". 4. Methodology and corpus. 5. Results. 5.1. Issues published on Venezuela. 5.2 Gender newspaper. 5.3 Dealing or tendency of the publications. 5.4 The sources of information. 5.5 The authors of the published information. 6. Conclusions. 7. Bibliography. 8. Notes.

\section{Introducción}

La comunicación y la información se están convirtiendo en el sector más dinámico en ciertas sociedades. Las industrias de la comunicación y la información, así como los servicios que de ellas emanan, han adquirido en ciertos países un peso económico tal que tienden a convertirse en dominantes y en un elemento crucial en la reproducción de patrones, cultura y conducta (Bustamante, 1982).

La comunicación es una herramienta no sólo de propaganda y de corte informativo, sino que resulta un campo de creación de imágenes. Es un instrumento de difusión y creación de sentidos, para un imaginario social cada vez más exigente en las formas y contenidos. Esas mediaciones en los receptores pueden darse por diversos factores: las provenientes del mismo receptor como sujeto cognoscente, miembro de una cultura y de un sistema social, las surgidas por la propia situación, las derivadas de medio de comunicación, las mediaciones de instituciones sociales y la mediación ejercida por el sustrato cultural del cual forma parte la audiencia (Orozco, citado por Pineda, 2004). 
Ante esas mediaciones, los medios juegan un papel determinante en el proceso de construcción, elaboración y transmisión de realidades y opinión pública, las cuales inciden directamente en la forma como el receptor conciba o deje de concebir el mundo que les rodea. "El lenguaje disfraza al pensamiento, y nos ha parecido que el análisis del disfraz nos entrega el inesperado trofeo del pensamiento difundido por los medios, especie mestiza, en la que pensamientos, sentimientos y vocabulario se confabulan para producir una realidad nueva" (Del Rey Morató, 1997:22).

La imagen país no escapa de esta realidad, pues los mensajes que a diario difunden los "mass media" pueden moldear y modificar la imagen que el público tenga sobre una determinada región de mundo, centrándose en unos hechos y dejando de lado otros. Una nación o país puede tener muchos hechos que comunicar o hacer saber a su colectividad, pero si éstos no entran dentro del campo comunicacional es como si nunca hubiesen existido y por ente jamás captarían la opinión pública.

Para López (1990) gran parte del conocimiento que los ciudadanos poseen se caracterizan por ser un conocimiento indirecto, moldeado por los medios de comunicación de masas, lo cual hace suponer que para la mayor parte de los individuos los medios de comunicación constituyen el eslabón principal de conexión con gran parte de nuestro entorno y con los cambios que tienen lugar en ese entorno.

Los medios actúan como megáfonos para difundir los acontecimientos de los países y escogen el tratamiento que le darán a determinados hecho con lo cual influyen en lo que ocupará los pensamientos de la gente y por consiguiente, moldean su imagen ya sea positiva 0 negativamente. Para Graber (1995) esta capacidad de moldear e influir en la opinión pública es más poderosa en aquellas noticias sobre las que el público carece de criterios propios como por ejemplo en aquellas que ocurre en lugares distantes, lo cual no le permite al receptor tener una visión más cercana de los hechos sino que construyen la realidad a través del discurso mediático.

Evidentemente, las nuevas significaciones que los individuos hagan sobre la realidad "real o imaginaria" de los países estará fuertemente influenciada por la agenda de los medios de comunicación y las agencias de publicidad y relaciones públicas y éstas estarán enmarcadas dentro de los intereses que posean los dueños de los medios sin olvidar que la libertad de expresión o de información "se falsea cuando es controlada por grupos que escamotean el ejercicio de esa libertad a sus pueblos, o cuando los países con menos recursos dependen, informativamente hablando, de las grandes agencias de los países desarrollados" (Tellería, 2005:85).

Lo antes expuesto obliga a pensar sobre el papel que desempeñan las grandes corporaciones mediáticas en el proceso de construcción de la imagen de los países no desarrollados o en vía de desarrollo, dado que tienden a usar todo el aparataje comunicacional y el poder mediático con miras a reproducir unos hechos que en ocasiones no se corresponde con la realidad de dicha nación, sino que están enmarcados en el favorecimiento de sus propios intereses económicos. 


\section{Objetivo}

Analizar la imagen que construyen los diarios con mayor tiraje y difusión en España sobre la República Bolivariana de Venezuela.

\section{Aspecto teórico}

\subsection{La imagen de país e imagen de marca país}

Hablar de imagen de país es referirse a todo aquello que de alguna u otra forma identifica a un determinado espacio territorial. Es la representación física o mental que un sujeto pueda hacerse, producto del resultado histórico de una serie de "acciones y reacciones entre el modo en que somos vistos, en el que nos vemos y en nuestra propia realidad" (Espinosa, citado por Lopes, 2005:126).

Existe una variedad de definiciones sobre la imagen país. A continuación se muestran las más relevantes para el presente estudio.

Tabla 1. Conceptualización de la imagen de país

\begin{tabular}{ll}
\hline \multicolumn{1}{c}{ Autor } & \multicolumn{1}{c}{ Definición } \\
\hline Choi (2006:3) & "A image is created by many different kinds of short pieces of knowledge, \\
& which are gained directly and indirectly over long periods of time. But a \\
& nation image is not fixed; rather, through the course of time, it is renewed \\
& by different factors [...] It is defined as created, gained, and changed \\
& directly and indirectly over time through different factors created by \\
& peoples reaction to different elements associated with it, such as media \\
& representation and international relationships.
\end{tabular}

Day, Skidmore, and Koller (2002:177)

Mackay

Fesenmaier

537)

Ortigueira 1999:72

Ross

Adapts

(1979)

Savage's (Citado por Suman, 2003)

Suman $(2003: 10)$ and A compilation of beliefs and impressions based on information processing (1997; from a variety of sources over time, resulting in an internally accepted mental construct $[\ldots]$ a composite of various products (attractions) and attributes woven into a total impression."

La imagen no es más que una representación mental de un fenómeno o sistema real, constituye la síntesis de las percepciones del individuo.

(1993: 54) "The sum of beliefs, ideas, and impressions that a person has of a Crompton's destination."

$(1976: 8) \quad$ A human construct imposed on an array of perceived attributes projected by an object, event, or person"

Image of nation is identified as the perceived attributes of a country by the media and the public. 
Fuente: Elaboración propia

En las definiciones anteriores, se observa que el concepto de imagen de país está totalmente vinculado con las percepciones, creencias e ideas que una persona tenga sobre un país o localidad, ya sea de forma positiva o negativa. Es decir, es una representación mental que los individuos se elaboraran partiendo de los factores internos o externos de la región.

De esta forma, en la formación de la imagen es fundamental determinar cuáles son los valores y características propias de la región dado que estas quedarán grabadas tanto en sus habitantes como en aquellas personas que de alguna u otra manera tengan contacto con dicha localidad. De acuerdo con Ortigueira, (2000) la representación mental que un individuo se haga sobre un país depende de ciertos aspectos como los geográficos, climáticos, económicos, políticos, sociales, culturales e incluso educativos; imagen que puede hacerse a través de dos procesos: aprehensión directa o indirecta.

Cuando se habla de aprehensión directa nos referimos a aquella que el sujeto adquiere en contacto con la realidad, a través de la convivencia en el sitio, el intercambio con las personas, compartiendo valores culturales y modo de vida. Es una interacción del individuo con el entorno y por ente tiende a conocer los aspectos característicos y culturales del lugar. Por su parte, la aprehensión indirecta está relacionada con la percepción que haga el sujeto sobre una realidad a través de elementos secundarios como lo son los medios de comunicación, los amigos y familiares, su formación académica. Estos elementos secundarios representan los ojos y oídos de aquellos que de algún u otra manera no han tenido un contacto directo y cercano con el país descrito.

No obstante, la imagen no es producto únicamente de aprehensiones directas o indirectas, ya que también son el fruto de las aprehensiones generadas por nuestra propia imaginación. Según Ortiguiera, (1999:72) ese proceso de "generación de «la imagen» es el responsable de la distancia existente entre la realidad y la percepción de ésta. Pero esta imagen, construida en nuestro universo particular, representa para su dueño la autentica realidad".

En otro sentido, desde la perspectiva del marketing y la economía, la imagen país suele ser asociada con la "imagen de marca de un país", la cual es el producto de la identidad distintiva: "una síntesis mental sustentada en valores" que persiste en la memoria sintética del público y está ligada a la marca/ producto, marca/empresa, marca/ servicio (Costa, 2004:162). La imagen estimula no sólo las decisiones de compra sino que moldea actitudes para que exista un intercambio cultural entre los ciudadanos de diferentes naciones.

De acuerdo con Tasci y Kozak (2006), la imagen de país y la imagen de marca país son dos conceptos que difieren entre sí en el cual la imagen país está sustentada en la utilización del patrimonio, el idioma, persona, mitos, leyendas y emblemas. "La formación de la imagen no es de marca, aunque el primero constituye el núcleo para la formación del segundo" (Tasci y Kozak, 2006:304). Por su parte, el concepto de imagen de marca se define como la "encarnación de la realidad abstracta en donde la gente compra productos o marcas de algo distinto de sus atributos físicos u funciones". Cuando se habla de imagen país se activa en la mente de las personas una percepción o un referente que en muchos casos no tiene ninguna vinculación con una marca ni con actividades de gestión económica. 


\subsubsection{Construcción de la "imagen país"}

Para los estudiosos de la imagen corporativa y la imagen de marca como: Corbu, (2009); Lopes (2005); Costa, (2004); Ortigueira, (2000); Álvarez y Caballero (1997); Alonso, (1993); Villafañe, (1992) y Ind, (1992) una imagen puede ser construida y reconstruida, a pesar de que sea un proceso que amerite tiempo, esfuerzo y una buena campaña comunicativa. De allí que la imagen de un país también pueda ser modificada "positiva" o "negativamente" a través de la implementación de una serie de estrategias que permitan difundir los valores $u$ atributos de la nación y por ende incidir en la percepción que el público o receptor posea.

Según Anholt (citado por Lopes, 2005) de la misma manera que una empresa, organización o institución puede mejorar el valor e imagen de sus marcas también puede hacerlo un país. Para ello, se deben identificar todos los aspectos que tienen relación directa con la imagen de país que actualmente se proyecta, precisar los elementos que se deseen modificar y, de acuerdo con unos objetivos claros y precisos, para así diseñar e implementar un plan que permita difundir la imagen que se desea perpetuar en la mente de los receptores.

Durante este proceso los medios de comunicación (radio, internet, televisión, prensa) juegan un papel fundamental, pues, al ser medios masivos pueden llegar a un mayor número de personas al mismo tiempo y con ello moldear sus percepciones. "El ciudadano corriente depende de los medios de comunicación de masas para formar sus concepciones de personas, grupos, situaciones nacionales y mundiales" (López, 1990:18). No obstante, existe un grupo menor de ciudadanos cuyo poder adquisitivo le permite viajar y con ellos constatar o refutar aquellos elementos que de forma constante se repiten en los mass media.

Para finalizar, es importante mencionar que aquellos interesados en modificar la imagen instaurada de una localidad, región o país deben ser conscientes que sus estrategias tienen que girar en torno al juego de las percepciones mentales de los individuos. Es decir, es una batalla que se gana cuando el público receptor llega a poseer la misma imagen "de país" de quienes emiten los mensajes.

\section{Metodología aplicada y corpus}

El presente estudio está sustentado en el análisis de contenido, el cual es método sistemático, cuantitativo y reflexivo que puede ser aplicado a distintos tipos de signos (verbales y no verbales). Para Krippendorff (1990) el análisis de contenido permite descubrir las imágenes o representaciones que contienen los textos, examina unidades de muestreo, registro y contexto, para tratar de averiguar cómo están representados o conceptualizados por medio del análisis de los atributos (perfiles o propiedades) que se le asignan y de las asociaciones y dis-asociaciones que se establecen.

El universo de esta investigación es "ad hoc" y está compuesto por tres periódicos españoles de información general (EI País, EI Mundo, ABC y la Vanguardia) los cuales se analizaron durante el 2009. Se escogieron dichos periódicos por ser los principales medios impresos de España considerando el promedio de su tiraje, su difusión y el tipo de difusión1 (ver tabla 2). 
Tabla 2. Tiraje y difusión de periódicos con información general

\begin{tabular}{llccccc}
\hline \multicolumn{1}{c}{ Periódico } & Periodicidad & $\begin{array}{c}\text { Tipo de } \\
\text { difusión }\end{array}$ & $\begin{array}{c}\text { Promedio } \\
\text { de Tirada }\end{array}$ & $\begin{array}{c}\text { Promedio de } \\
\text { Difusión }\end{array}$ & $\begin{array}{c}\text { Periodo } \\
\text { Controlado }\end{array}$ & Información \\
\hline El País & Diario & Pago & 524.507 & 401.392 & $\begin{array}{c}\text { Julio-2008/ } \\
\text { Junio-2009 }\end{array}$ & General \\
El Mundo & Diario & Pago & 408.736 & 309.995 & $\begin{array}{c}\text { Julio-2008/ } \\
\text { Junio-2009 }\end{array}$ & General \\
ABC & Diario & Pago & 343.640 & 257.018 & $\begin{array}{l}\text { Julio-2008/ } \\
\text { Junio-2009 }\end{array}$ & General \\
La & Diario & Pago & 235.361 & 200.982 & $\begin{array}{c}\text { Julio-2008/ } \\
\text { Junio-2009 }\end{array}$ & General \\
Vanguardia & & & Fuente: Elaboración propia según la OJD española
\end{tabular}

Fuente: Elaboración propia según la OJD española

Con miras a obtener representación equitativa de cada unos de los periódicos se efectuó el cálculo de la muestra tomando en cuenta cada estrato o diario por ello se analizaron 316 ediciones (79 de cada uno). Seguidamente se realizó el cálculo del "salto sistemático" para escoger de forma sistemática el número de diarios que corresponden analizar.

Al precisar el número de ediciones a estudiar se determinaron las fechas a las que corresponden cada una de ellas. Así como el número de informaciones que de alguna u otra forma estaban vinculadas a Venezuela ya sea de forma directa ${ }^{2}$ o indirecta ${ }^{3}$. Para ello, se consideraron los diversos textos periodísticos publicados en las portadas, los destacados en la primera página, los textos en el interior del cuerpo y el código icónico empleado por el diario.

A continuación, en la tabla 3 se presenta una muestra con las fechas de los diarios con información general que se emplearon para efectuar el análisis.

Tabla 3. Muestra de las fechas de las ediciones a analizar "diarios con información general"

\begin{tabular}{|c|c|c|c|c|c|c|c|c|c|c|c|c|}
\hline \multirow[b]{2}{*}{ No. } & \multicolumn{3}{|c|}{ Diario El País } & \multicolumn{3}{|c|}{ Diario el Mundo } & \multicolumn{3}{|c|}{ Diario ABC } & \multicolumn{3}{|c|}{ Diario La Vanguardia } \\
\hline & $\begin{array}{l}\text { Edic. } \\
\text { Aleata }\end{array}$ & Fecha $^{3}$ & Núm. Inform. & Edic. Aleat. & Fecha & $\begin{array}{l}\text { Núm. } \\
\text { Intorm }\end{array}$ & Edic. Aleat. & Fecha & Núm. Intorm. & $\begin{array}{l}\text { Edic. } \\
\text { Aleat }\end{array}$ & Fecha & Núm. Inform \\
\hline 1 & 78 & 20.03 & 2 & 9 & $10-01$ & Intorm. & 13 & 14.01 & 0 & $\begin{array}{l}\text { Aleat. } \\
92\end{array}$ & $03-04$ & 1 \\
\hline 2 & 83 & $25-03$ & 0 & 14 & $15-01$ & 0 & 18 & $19-01$ & 1 & 97 & $08-04$ & 0 \\
\hline 3 & 88 & 30.03 & 1 & 19 & $20-01$ & 0 & 23 & $24 \cdot 01$ & 1 & 102 & 13-04 & 0 \\
\hline 4 & 93 & $\begin{array}{l}04-04 \\
\end{array}$ & 0 & 24 & $25-01$ & 0 & 28 & 29.01 & 0 & 107 & 18-04 & 2 \\
\hline 5 & 98 & $\begin{array}{l}09-04 \\
\end{array}$ & 0 & 29 & $30-01$ & 1 & 33 & 03.02 & 0 & 112 & $23-04$ & 2 \\
\hline
\end{tabular}

Fuente: Elaboración propia

En total se encontraron 218 trabajos periodísticos en los diferentes diarios (78 El País, 49 El Mundo, 57 ABC y 34 La Vanguardia). De los cuales se puede apreciar que el diario el País es el medio que mayor número de publicaciones tiene sobre Venezuela, sus personajes, organizaciones e instituciones, seguido del periódico ABC. 


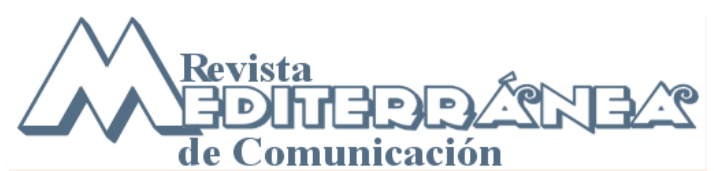

ISSN 1989-872X - Año 2 (2011), pp. 15-42

\section{Resultados}

\subsection{Temas publicados sobre Venezuela}

En este apartado se presentan los principales temas que se encontraron en las publicaciones estudiadas. La tabla 4 contiene de manera descendente los temas ubicados.

Tabla 4. Temas en los cuales se vinculó a Venezuela

\begin{tabular}{|c|c|c|c|c|}
\hline No & Temas & Frecuencia & Porcentaje & $\begin{array}{l}\text { Porcentaje } \\
\text { acumulado }\end{array}$ \\
\hline 1 & $\begin{array}{l}\text { Situación de Venezuela a causa de su } \\
\text { sistema de gobierno }\end{array}$ & 68 & 31,2 & 31.2 \\
\hline 2 & $\begin{array}{l}\text { Vinculación con el resto de } \\
\text { Latinoamérica }\end{array}$ & 47 & 21,6 & 52,8 \\
\hline 3 & $\begin{array}{l}\text { Relación con los países miembros del } \\
\text { ALBA }\end{array}$ & 43 & 19,7 & 72,5 \\
\hline 4 & Otros & 29 & 13,3 & 85,8 \\
\hline 5 & $\begin{array}{l}\text { Relación con los Estados Unidos de } \\
\text { Norteamérica }\end{array}$ & 17 & 7,8 & 93,6 \\
\hline 6 & Relación con España & 14 & 6,4 & 100 \\
\hline & Total & 218 & & \\
\hline
\end{tabular}

En primera instancia se observó que las informaciones estaban orientadas a reflejar la "situación interna de Venezuela a causa de su sistema de gobierno" con un $31,2 \%$. Dentro de esta categoría los diarios abordaron diversos escenarios como: la escasez de agua y los problemas eléctricos, la delincuencia, la situación o persecución que viven las personas que se oponen al gobierno bolivariano (como es el caso del ex- gobernador Manuel Rosales), la situación de la salud pública, la recesión económica de Venezuela, la nacionalización de las principales empresas que operan en el país como las petroleras o las bancarias, las medidas educativas desarrolladas por el gobierno, la situación de la libertad de expresión y los medios de comunicación y el sistema democrático del país.

Todos estos temas son justamente las matrices de opinión que las empresas de comunicación arrojan en Venezuela para crear la imagen de una Venezuela inestable y en crisis. Son temas que en algunos casos están descontextualizados y no tienen la profundidad requerida para tener una cobertura idónea. Por ello, explicaremos algunos ejemplos de las situaciones que los medios omitían en la difusión de los trabajos: 


\section{a) La escasez de agua y los problemas eléctricos en Venezuela}

Cada cuatro o siete años, en el Pacífico se produce un fenómeno que afecta a la circulación de masas de agua en el océano y la dinámica atmosférica, y causa alteraciones importantes en el clima mundial. Dicho fenómeno es conocido con el nombre del Niño. Durante el 2009, ese fenómeno natural afectó gravemente a Latinoamérica causando mucha sequía por la falta de precipitaciones.

Diversos países en América Latina se vieron afectados. Ecuador se declaró en emergencia eléctrica, lo mismo ocurrió con Colombia y Chile, el gobierno colombiano dejó de vender energía a Venezuela como consecuencia de sus problemas de generación. De allí que Venezuela se viera afectada por los problemas eléctrico y el racionamiento del agua.

En el abordaje periodístico que los medios hicieron sobre la escasez de agua y los problemas eléctricos de Venezuela no vinculaban la problemática con el fenómeno que afectaba la región latina, sino con las políticas de gobierno del mandatario venezolano. Como ejemplo se puede presentar la publicación realizada por el diario la Vanguardia bajo el título "Yo no quedo hediondo" del 30 de octubre de 2009, en cuyo texto se relaciona la mala gestión del gobierno con el racionamiento eléctrico y de agua que tuvo la población venezolana.

"Entre racionamientos de agua, cortes de luz e inseguridad ciudadana se desarrolla la vida cotidiana de muchos venezolanos a los que Chávez exige austeridad y ahorro. La situación ha llegado al extremo de que el diario caraqueño Tal cual dedicara ayer la primera página a un editorial de su director, Teodoro Petkoff, con un título chocante: "Bienvenidos a Ciudad Gotica".

Con un humor que habrá hecho poca gracia a Chávez, Petkoff describía el estado de postración en que se halla Caracas: "Ni gotica de agua, ni gotica de luz, ni gotica de seguridad. Ni gotica de nada".

Los apagones se han convertido en parte de la cotidianidad de los venezolanos. Como en tantas otras cosas, se sigue los pasos de Cuba al establecer estrictos racionamientos de agua y electricidad. Un país atravesado por ríos caudalosos (Orinoco, Guárico, Caroní, Guainía) y construido sobre un mar de petróleo lucha para dar de beber a su gente y para mantener encendidas las luces.

Una sequía récord, años de mala planificación, falta de mantenimiento y retrasos en inversiones para generar y suministrar energía provocan que los apagones y la falta de agua sean hechos frecuentes en gran parte de Venezuela, lo que ocasiona protestas que Chávez intenta apaciguar sin mucho éxito". 


\section{b) La persecución política}

De acuerdo con las informaciones publicadas se da por hecho que el gobierno bolivariano persigue a todo aquel que llegue a pensar de forma diferente. No obstante, en Venezuela no se ha privado de su libertad a ningún periodista por publicar información veraz. Gustavo Azócar, periodista y dirigente opositor, fue procesado judicialmente pero por estafa.

En el caso del dirigente Manuel Rosales los cargos que se le imputan son por enriquecimiento ilícito. A Rosales se le acusa de adquirir una serie de bienes inmuebles a lo largo de las gestiones en los diferentes cargos de elección popular (Alcaldía de Maracaibo y la gobernación del Estado Zulia) que desempeñó en la entidad. Manuel Rosales es dueño de siete viviendas, un centro comercial y participa en 13 empresas ubicadas en el estado de Florida, entre ellas la Agropecuaria La Milagrosa, presidida por él junto a una funcionaria de la gobernación. También es dueño de RT International Group. Aparentemente tiene testaferros para propiedades con un valor de más de 3 millones de dólares, formada por sus hijos, hermanos y cuñados.

Durante el lapso de la verificación efectuada por la Contraloría General de la República de Venezuela, Rosales no logró justificar la totalidad de los recursos administrados, durante el período evaluado, determinándose un incremento en el patrimonio no justificado por la cantidad en bolívares de 147 millones 389 mil 966 con 67 céntimos, (el equivalente a 68.553 dólares). De allí que Rosales huyera de Venezuela y se exiliara en Perú.

Este tipo de datos sobre la situación de Rosales tampoco difunden por la prensa sino que el discurso lo construyen de tal forma que el receptor se forme la idea de que se le persigue sólo por oponerse al actual gobierno del país. Un ejemplo de ello lo constituye la publicación hecha por el diario El Mundo bajo el título "Rosales avisa a Chávez de que se juega una revuelta popular" de fecha 21 d emarzo de 2009.

"La fiscal del Ministerio Público, Kaiuska Plaza, ha pedido la detención por enriquecimiento ilícito de uno de los más duros adversarios de Chávez en la arena política. La causa que se remonta a 2007, imputa a Rosales un delito de fraude fiscal agravado que se sanciona con entre 10 años de presión.

Pero el que fuera candidato en las elecciones presidenciales de 2006 está convencido de que fue su enemigo quien ordenó "desempolvar» el caso, para descabezar a la oposición y seguir avanzando en el plan hegemónico que sus adversarios le atribuyen"

La redacción de dicha información hacía entrever que a Rosales se le persigue por ser opositor al gobierno del presidente Chávez dándole poca importancia a los actos que se le imputan.

\section{c) La recesión" en Venezuela}

El diario El País publicó un texto el 20 de diciembre de 2009 con el título "Venezuela anclada en la recesión". Este trabajo posee una fotografía (ver figura 1) cuyo pie de foto dice: "Compradores y visitantes abarrotan un centro comercial muy popular de Caracas" lo cual hace suponer que la fotografía fue tomada en algún centro comercial de la capital venezolana, pero no especifican el nombre del lugar. 
Figura 1. Fotografía del texto "Venezuela anclada en la recesión"

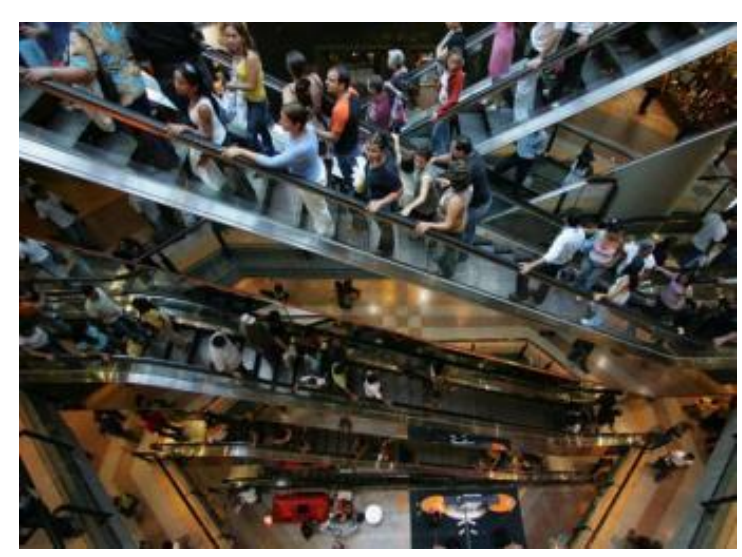

Fuente: Diario El País, 20 de diciembre de 2009.

Si analizamos esa fotografía (con su pie de foto) y el subtítulo del texto publicado "La inflación más alta en América Latina obliga a los venezolanos a apretarse el cinturón" vemos que existe una incongruencia entre el texto plasmado y la fotografía pues sí la mala situación de Venezuela "obliga a los venezolanos a apretarse el cinturón" ¿cómo es posible que exista tantas personas que "abarrotan un centro comercial" como publica el mismo medio.

Pero allí no queda el tratamiento informativo del diario El País, pues en la investigación efectuada se pudo conocer que el mismo medio publicó el 30 de julio del mismo año una información denominada "La cultura del despilfarro tardará en volver" (con mención a España) en la cual se hacía uso de la misma fotografía que "supuestamente" corresponde a un centro comercial de Caracas.

El pie de foto de la publicación efectuada en junio decía. "El español ha cambiado el centro comercial y el restaurante por la comida en casa y la fiambrera en el trabajo". Entonces surge una interrogante, ¿cuál es la procedencia de esa fotografía, pertenece a un centro comercial venezolano o español? El uso de la misma fotografía para representar hechos y lugares distintos constituye una manipulación de la realidad y una tergiversación de los datos publicados. 
Figura 2. Fotografía publicada para reseñar dos informaciones distintas y de distintos países
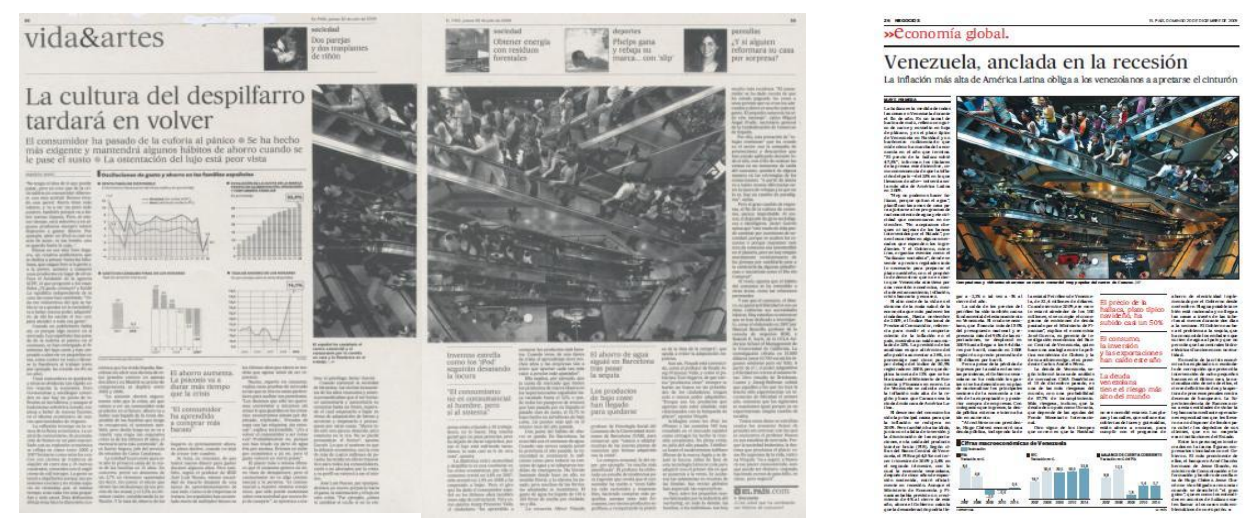

Fuente: Diario El País, 30 de julio y 20 de diciembre de 2009.

El Manual de Estilo del País de España, en la "sección 5 punto 1.3.4" expresa que en caso de emplear imágenes de archivos, el periodista debe tener cuidado y expresar en el pie de la misma la fecha en la cual se tomó y la situación a la que corresponde la fotografía.

La fotografía publicada carece de fecha e incluso confunde al lector sobre la situación a la que corresponde la foto y el lugar, lo único que se conoce es que procede de la Associated Press (AP), esto evidencia que con la publicación de estos trabajos se incumple incluso el propio manual del medio.

El segundo tema abordado por los diarios en estudio fue la "vinculación de Venezuela con el resto de los países de América Latina" (21,6\%). En este caso se le da un mayor énfasis a la relación Venezuela-Brasil, Venezuela-Argentina, Venezuela- Colombia, Venezuela-El Salvador. A continuación se presentan, a manera de ejemplo, los principales tratamientos que se efectuaron en torno a la vinculación de Venezuela con Brasil y Colombia.

a) Venezuela - Brasil

Dentro de estas informaciones se hace mención a las medidas que en materia económica y política implementa el presidente Luiz Ignacio Lula Da Silva, para conducir al pueblo brasileño y se compara con la forma como gobierna el presidente venezolano. Por ejemplo el artículo de opinión titulado "El Eje de Lula y el eje de Hugo", publicado el 22 de marzo de 2009 por el diario El País plantea lo siguiente:

"Mientras que los países del Eje de Hugo construyen su alianza antiyanqui y aplican lo que el presidente venezolano denomina "el socialismo del siglo XXI", el Gobierno brasileño está desarrollando con gran éxito un proyecto geopolítico muy distinto: construir alianzas que le den a Brasil voz y voto en las grandes decisiones que afectan a la humanidad".

En esta publicación el diario el País ensalza el sistema de gobierno del mandatario Luiz Ignacio Lula, tratamiento que puede derivarse de los vínculos económicos existentes entre españoles y 
brasileños, pues dicha nación suramericana es el principal socio comercial de España en Latinoamérica ${ }^{7}$.

\section{b) Colombia- Venezuela}

Se construye una imagen de una Venezuela que apoya a las Fuerzas Armadas Revolucionarias de Colombia (FARC) y que está vinculada con el narcotráfico.

En el texto "«Colombia no está interesada para nada en que se acabe el narcotráfico, es un narcoestado»", difundido por el ABC el 22 de marzo de 2009 se muestra un ejemplo de la forma como relacionan a Venezuela y a su presidente con el tema colombiano.

"Convertido en algo más que un profesional de la provocación, el presidente venezolano ha decidido llevar hasta el extremo de la conflictividad cualquier relación diplomática que no se atenga a los principios de su presuntuosa «revolución bolivariana» 0, simplemente, que no le baile el agua en su cruzada «populista» contra el resto del mundo. Chávez está decidido a romper sus relaciones diplomáticas con el Gobierno colombiano de Álvaro Uribe y para lograrlo no sólo impulsa una cínica victimización de Venezuela, sino que acusa por acusar y con el único ánimo de hacer daño. No está mal viviendo precisamente de un caudillo a quien los indicios y las pruebas que no presenta contra Uribe sí le pesan a él como una losa por sus vinculaciones con las FARC, una «narcoguerrilla» en toda regla".

El trabajo publicado por el $A B C$ construye la imagen de un Presidente (venezolano) "un caudillo populista" que busca una "presuntuosa revolución bolivariana" e impulsa "una cínica victimización" de Venezuela. Colombia, el mayor productor de droga del mundo ${ }^{8}$, tienen una imagen legítima, mientras que el gobierno venezolano sólo "acusa por acusar".

Un segundo ejemplo que se puede suministrar sobre la relación Colombia -Venezuela es el texto "Uribe intenta enfriar Sur América”, publicado por el diario el País (ver figura 3).

Figura 3. Relación Venezuela - Colombia

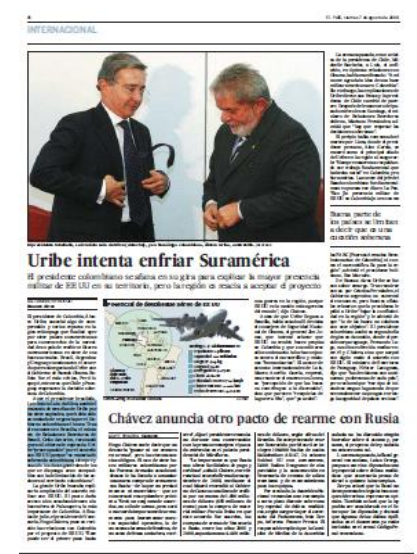

Fuente: Diario El País, 7 de agosto de 2009.

"El presidente de Colombia, Álvaro Uribe, cosechó algo de comprensión y varios reparos en la gira relámpago que finalizó ayer por siete países suramericanos para convencerlos de la necesidad de recibir militares norteamericanos en siete de sus bases actuales. Brasil, Argentina y Uruguay cuestionaron el acuerdo que está 
negociando Uribe con el Gobierno de Barack Obama. Bolivia fue el más crítico, mientras que Chile y Paraguay respetaron la decisión soberana de Colombia [...]

A finales de julio, el presidente de Venezuela, Hugo Chávez, puso en revisión as relaciones con Colombia por el proyecto de EEUU. "Éste puede ser el primer paso hacia una guerra en la región porque EEUU es la nación más agresiva del mundo" dijo Chávez".

En dicho trabajo periodístico se construye la imagen de un Uribe que busca alianzas en Latinoamérica que justifiquen la instalación de las siete bases militares estadounidenses en el territorio colombiano. El redactor "Alejandro Rebossio" en el desarrollo del trabajo, deja claro que Brasil y Argentina no están muy a favor del acuerdo militar con los Estados Unidos. No obstante, los gobiernos con tendencia de izquierda Venezuela, Bolivia son aquellos quienes se mantienen más críticos.

Y como una forma de reafirmar el conflicto bélico que se puede presentar en Latinoamérica a causa de la decisión del gobierno colombiano los editores del diario colocan debajo de la publicación anterior un texto denominado "Chávez anuncia otro pacto de rearme con Rusia".

El tercer tema que trataban los diarios estaba centrado en mostrar la "relación de Venezuela con los países miembros del ALBA" con una presencia de 19,7\%. Dentro de este tema se pudo constatar que existe un predominio al momento de relacionar a Venezuela (Hugo Chávez) con Bolivia (Evo Morales), Nicaragua (Daniel Ortega), Cuba (Raúl Castro), Ecuador, (Rafael Correa) e, incluso, Honduras cuyo gobierno de facto optó por retirarse de dicha organización luego del 28 de junio de 2009 cuando se realizó el golpe de Estado en contra del presidente Manuel Zelaya.

El Presidente venezolano, Hugo Rafael Chávez Frías, es denominado por el diario El País como el heredero de Fidel, en un claro desconocimiento y negación de la integración de los pueblos latinoamericanos. Daniel Ortega, Evo Morales y Rafael Correa son catalogados como los seguidores del "modelo chavista". En los cuatro diarios en estudio, dichos gobiernos se relacionan entre sí por sus ideologías izquierdistas y por sus constantes políticas antiimperialistas.

Figura 4. Fotografía publicada para reseñar dos informaciones distintas de la relación Venezuela - ALBA

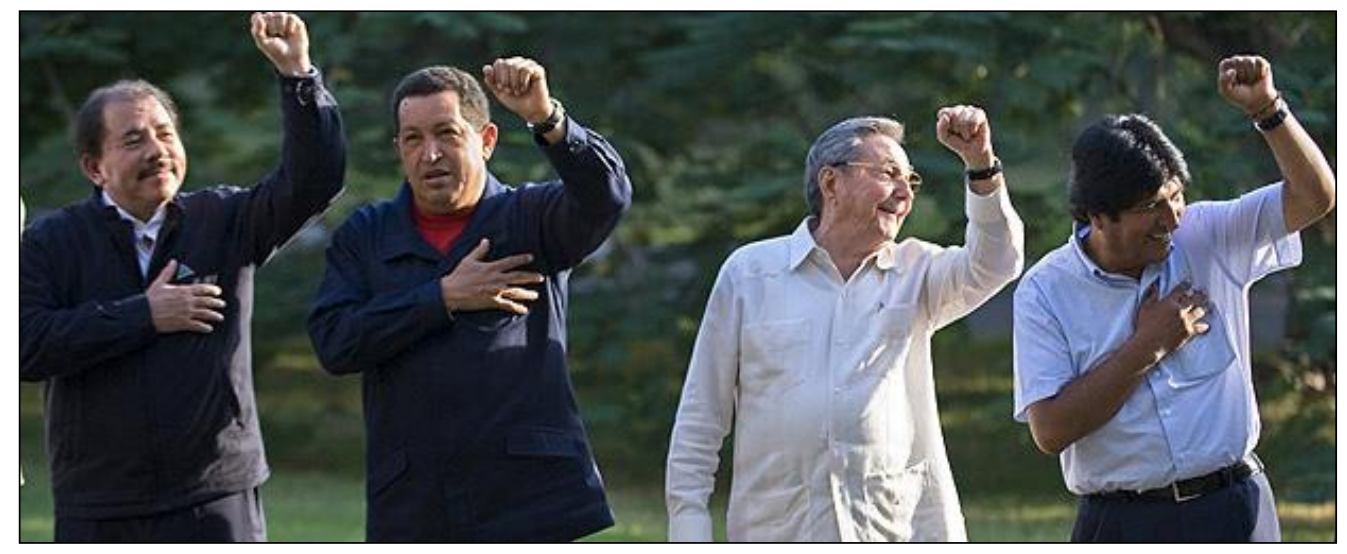

Fuente: Diario El País, 15 y 31 diciembre de 2009. 
La fotografía anterior es un ejemplo del constante intereses de los redactores de relacionar a los gobiernos de izquierda textual y gráficamente, pues a pesar de abordar temas diferentes "Chávez y sus aliados sacan pecho ante las advertencias de Washington" y "América Latina 1999-2009, el péndulo implacable y la incertidumbre" emplearon la misma imagen.

Al observar el título "América Latina 1999-2009, el péndulo implacable y la incertidumbre" unido a la fotografía queda evidente que "el péndulo implacable y la incertidumbre" no es en toda Latinoamérica sino en esos cuatro países los cuales tienen gobiernos con ideologías de izquierda.

Es importante destacar que en ocasiones, aunque la información no abordaba un tema relacionado directamente con Venezuela, sino con otros países del ALBA, gráficamente se vinculaba al mandatario venezolano. La figura 5 muestra algunos ejemplos en los cuales se vinculan directamente a los gobiernos con tendencia izquierdista.

Figura 5. Relación de gobiernos con tendencias izquierdistas
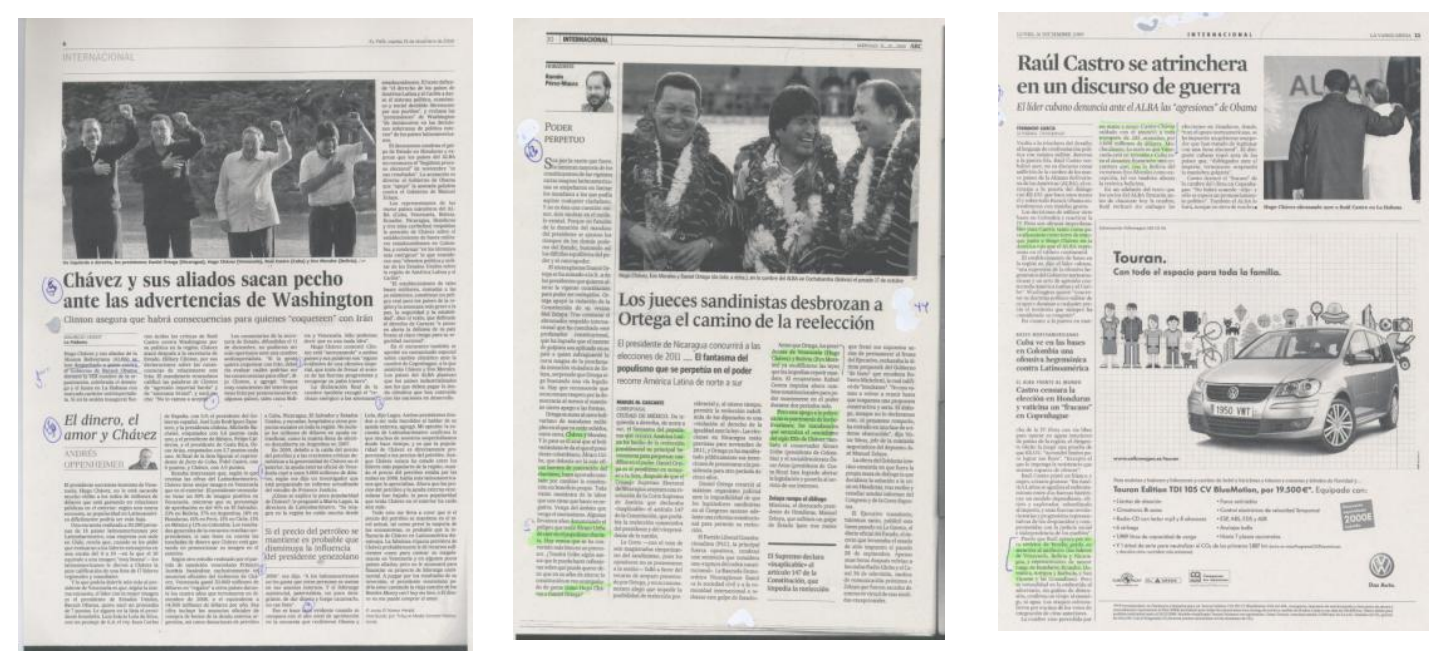

Fuentes: Diarios El País, 15 de diciembre; ABC, 21 de octubre y La Vanguardia, 14 de diciembre de 2009.

Cuando se publican informaciones respecto a la integración de los gobiernos de Chávez, Correa, Castro, Morales u Ortega, tratan de hacerlos ver como un eje conflictivo, populista, corrupto y pobre. Un ejemplo de ello serían las publicaciones:

a) "Raúl Castro se atrinchera en un discurso de guerra", publicado el 14 de diciembre de 2009 por la Vanguardia

"La cumbre vino precedida por un mano a mano castro-Chávez saldado con el anuncio a toda trompeta de 285 acuerdos por 3.000 millones de dólares. Mucho dinero. Lo malo es que Venezuela está en recesión y Cuba rosa el desastre financiero: una coyuntura que con la Bolivia del victorioso Evo Morales como excepción, tal vez también alienta la retórica belicista".

b) "Chávez reinventa la guerra fría en los Andes", publicada el 8 de agosto de 2009 por El Mundo. 
"Y es que Venezuela y sus aliados (Cuba, Nicaragua, Ecuador y Bolivia) han iniciado una ofensiva diplomática y propagandística contra Uribe y contra Obama. Hugo Chávez habla abiertamente de la amenaza de «invasión» de EEUU y Fidel Castro califica las bases militares de "puñales en el corazón de América».

Los esfuerzos de Obama para reducir la brecha con el eje chavista -la suavización de las sanciones a Cuba y la condena del golpe en Honduras son sólo dos ejemplosparecen estrellarse en una muralla. Aunque sean pura retórica, los epítetos utilizados por Chávez, Castro, Evo Morales, Daniel Ortega y Rafael Correa contra este nuevo acuerdo militar de EEUU parecen más discursos de la Guerra Fría que respuestas ajustadas a la realidad".

El cuarto tema abordado por los diarios analizados es la "relación de Venezuela y Estados Unidos" con un $7,8 \%$. En dichas publicaciones se mostraban la forma cómo se ha venido llevando las relaciones entre ambas naciones. Obama es representado como un presidente que busca mejorar las relaciones con los países latinoamericanos, mientras que Venezuela se muestra como un país que aún sigue atacando las políticas estadounidenses. Veamos los siguientes ejemplos:

a) "Obama reclama «hechos» a Castro", publicado por el diario La Vanguardia el publicado el 20 de abril de 2009.

"[...] el venezolano Chávez y sus socios del ALBA (la Alternativa Bolivariana para América Latina y el Caribe, formada por Bolivia, Cuba, Dominica, Honduras, Nicaragua y Venezuela) quitaron importancia para no estropear el buen ambiente creado desde que Obama prometió al principio abrir una relación "de igual a igual" con sus vecinos [...] Obama también ve "potenciales señales positivas" de la parte cubana, así como de Venezuela [...] Pero tanto Cuba como Venezuela se perfilan -dijo el líder de EE.UU.como "un test" para el desarrollo real de la "nueva era de asociación" que dio por inaugurada tras el encuentro en Trinidad".

Este tema es abordado por La Vanguardia como si fuese la época colonial en la cual un gobierno tiene potestad de decidir sobre el destino de los demás países y obliga a preguntarse ¿Por qué Estados Unidos debe indicar, de acuerdo con su criterio, si son buenas o malas las políticas internas de las naciones del Sur?.

b) "Chávez desafía a Obama" editorial del ABC publicado el 27 de agosto de 2009.

\begin{abstract}
"Por otro lado el desafío de los sectores movilizados por Hugo Chávez se dirige también hacia el Presidente norteamericano Barack Obama, puesto que Washington es el otro firmante de ese acuerdo de cooperación militar. Hasta ahora la casa Blanca ha intentado un equilibrio imposible, tratando de preservar esa especie de luna de miel con los sectores populistas que siguió a la elección del candidato demócrata. Este conflicto diplomático debería servir para demostrar claramente que no es posible mantener una esta equidistancia artificial“.
\end{abstract}

Dicho editorial construye la imagen de un presidente norteamericano que busca ayudar a combatir el narcotráfico en Colombia y que intenta mantener relaciones armoniosas con los distintos gobiernos latinoamericanos. No obstante, las acciones que ejecuta el gobierno venezolano (Chávez) no hacen posible unas buenas relaciones diplomáticas entre EU y Venezuela de allí que el dirigente estadounidense deba tomar acciones sobre sus políticas con Latinoamérica. 
Por último, tenemos el tema "relación Venezuela- España", el cual ocupó un $6,4 \%$ en las informaciones analizadas. Las publicaciones de los diarios estaban enmarcadas en reflejar la inseguridad jurídica e institucional que presentan el gobierno venezolano para los españoles residentes que tienen negocios y propiedades en Venezuela así como para aquellos que deseen invertir en el país.

El Ministro de relaciones Exteriores de España, Miguel Ángel Moratinos, es mostrado como una persona que además de velar por los intereses de los españoles "apoya" las políticas internas que desarrolla el gobierno de Venezuela.

El representante del gobierno español, Miguel Moratinos, es el mediador entre los empresarios españoles y administración venezolana y quien tuvo que influir "según las informaciones publicadas" en la búsqueda de una salida exitosa en cuanto a la compra que hizo el Estado venezolano sobre el Banco Santander. Compra que fue reseñada de forma negativa por dichos diarios haciendo énfasis en que fue una compra hostil en donde el gobierno de Venezuela no pagó el monto suficiente para adquirir la entidad financiera.

El discurso empleado por los redactores es de una Venezuela en la cual no se puede invertir por los riesgos que representa el gobierno del presidente Chávez. Sin embargo, el país venezolano representa una gran oportunidad para inversionistas en el área de telefonía, hotelería y petrolera. Un ejemplo de ello es la información "Moratinos dice que «España confía en la Venezuela del Presente y del futuro»", publicada por el ABC el 28 de julio de 2009 en la cual se expone las nuevas inversiones de España en la república bolivariana.

"Hay tres empresas que tienen altas probabilidades de firmar hoy operaciones. Una es Iberdrola, que construirá una planta de ciclo combinado de generación de electricidad por gas en el estado Sucre, por valor de 2.000 millones de dólares, Repsol, por su parte, tendrá que vender al Estado venezolano sus participaciones en la central de Termobarranca como consecuencia de la nacionalización del sector, por otra parte, creará una empresa mixta con PDVSA y firmará un acuerdo de compensación de deuda con esta empresa para que le pague en crudo los 200 millones de euros que le debe.

La información publicada por el ABC muestra una contradicción entre el abordaje de las informaciones y la situación de los empresarios españoles en Venezuela, pues a pesar de que en los diarios analizados se muestra una Venezuela que "no tiene garantía institucional y jurídica" para que efectúen inversiones, se observa que los empresarios españoles se afianzan en el país como es el caso de las empresas Repsol, Iberdrola y Telefónica; entre otras.

\subsection{Géneros periodísticos}

En cuanto al tipo de publicaciones que los diarios El País, El Mundo, ABC y La Vanguardia hicieron sobre Venezuela se observó que la noticia es el género periodístico más empleado con un $58,7 \%$ (ver tabla 5 ). 
Tabla 5. Géneros periodísticos publicados

\begin{tabular}{llccc}
\hline No & Género Periodístico & Frecuencia & Porcentaje & $\begin{array}{c}\text { Porcentaje } \\
\text { acumulado }\end{array}$ \\
\hline 1 & Noticia & 128 & 58,7 & 58,7 \\
2 & Artículo de Opinión & 34 & 15,6 & 74,3 \\
3 & Otros & 24 & 11,0 & 85,3 \\
4 & Editorial & 16 & 7,3 & 92,6 \\
5 & Entrevista & 12 & 5,5 & 93,6 \\
6 & Reportaje & 4 & 1,9 & 100 \\
\hline & & 218 & \multicolumn{2}{c}{ Fuente: Elaboración propia }
\end{tabular}

En el periodismo, se entiende por noticia a aquella publicación que se hace sobre un tema de interés colectivo y en el cual el periodista o redactor sólo actúa de intermediario (entre el suceso ocurrido y el público) para dar a conocer los hechos. Llama la atención la forma cómo los periodistas de dichos diarios abordan y estructuran sus "noticias", pues la investigación ha permitido conocer que el $53,9 \%$ de las noticias publicadas estaban cargadas de juicios de valor $u$ opiniones de los redactores (ver tabla 6), lo cual es propio de los géneros de opinión, pero no de las noticias.

Tabla 6. Noticias con juicios de valor

\begin{tabular}{ccccc}
\hline No & Juicios de valor & Frecuencia & Porcentaje & $\begin{array}{c}\text { Porcentaje } \\
\text { acumulado }\end{array}$ \\
\hline 1 & Con juicios de valor & 69 & 53,9 & 53,9 \\
2 & Sin juicios de valor & 59 & 46,1 & 100 \\
\hline & Total & 128 & & \\
& & & Fuente: Elaboración propia
\end{tabular}

Es decir, que los redactores cuando escriben una noticia no se limitan a mostrar los acontecimientos y los actores implicados, sino que además ejercen un papel o función "ser críticos" que no les corresponde dado el tipo de género periodístico que emplean para dar a conocer los sucesos (ver tabla 7). 
Tabla 7. Ejemplos de juicios de valor u opinión en las noticias

\begin{tabular}{|c|c|c|c|}
\hline Diario & Fecha & Título & Opinión del redactor \\
\hline $\mathrm{ABC}$ & 09-04-09 & $\begin{array}{l}\text { El Presidente } \\
\text { venezolano busca en } \\
\text { Asia clientes para sus } \\
\text { recursos }\end{array}$ & $\begin{array}{l}\text { "El presidente Hugo Chávez ha demostrado que } \\
\text { puede mandar por control remoto en Venezuela } \\
\text { desde el exterior, que sus órdenes serán cumplidas a } \\
\text { pide juntillas" }\end{array}$ \\
\hline $\begin{array}{l}\text { La } \\
\text { Vanguardia }\end{array}$ & $18-04-09$ & $\begin{array}{l}\text { Castro y Obama rozan } \\
\text { diálogo }\end{array}$ & $\begin{array}{l}\text { "Nubes y claros con ambiente apacible y riesgo de } \\
\text { lloviznas en Trinidad y Tobago al inicio de la V } \\
\text { Cumbre las Américas. El parte metereológico, } \\
\text { auténtico, vale también para la atmósfera de sol con } \\
\text { pocas sombras que envolvía Puerto España [...] el } \\
\text { presunto gran amigo de los Castro, Hugo Chávez, } \\
\text { hacía circular nubes plomizas al amenazar con } \\
\text { romper la cumbre y cubanizarla en exceso". }\end{array}$ \\
\hline
\end{tabular}

Fuente: Elaboración propia

Estos ejemplos demuestran el tipo de periodismo que realizan estos medios. La noticia como género periodístico debe escribirse de forma tal que el redactor ponga de manifiesto el hecho y sea el lector quien saque sus propias conclusiones sobre lo leído. El Manual de Estilo del diario El País (Sección 3 -Tratamiento de la información- punto 1.12) plantea que el periodista transmite a los lectores noticias comprobadas, y se abstiene de incluir en ellas sus opiniones personales, es decir nuevamente se incumple las normas del medio.

En cuanto al resto de los géneros publicados se observó que los artículos de opinión ocuparon un $15,6 \%$ seguido por los editoriales $7,3 \%$ y la entrevista 5,5\%. Dentro de la categoría de otros $(11 \%)$ se ubicaron las publicaciones como: cartas del lector, reseñas y recuadros informativos. Publicaciones donde se abordaba el tema de Venezuela pero de forma muy sucinta y escueta, incluso sin el uso de fuentes informativas.

Sólo en un 1,9\% se empleó el reportaje como género periodístico para difundir los hechos de índole venezolano. Lo cual pone en evidencia que los medios tienen poco interés al momento de hacer una cobertura periodística a profundidad y con investigación para abordar y publicar un acontecimiento relacionado con Venezuela.

\subsection{Tratamiento o tendencia de las publicaciones}

Una vez conocidos los diferentes temas con los cuales la prensa con mayor difusión en España (ABC, EL País, EL Mundo y La Vanguardia) aborda la realidad venezolana, el siguiente paso es conocer cuál es el tratamiento periodístico que le dan a dichos hechos, es decir si se abordan desde una perspectiva, positiva, negativa o neutra. 
La investigación permitió conocer que durante el 2009 la cobertura que hicieron dichos diarios sobre Venezuela fue negativa en un $81,7 \%$, lo que demuestra que los temas anteriormente descritos son enfocados en su gran mayoría con miras a construir una imagen deslegitimada de este país. Sólo en un $2,8 \%$ se publicaron trabajos periodísticos desde una perspectiva positiva (ver tabla 8).

Estos resultados cuentan con un intercoder reliability ${ }^{9}$ de $80 \%$, lo cual le da validez y comprueba la fiabilidad de los resultados obtenido.

Tabla 8. Tratamiento o tendencia noticiosa de Venezuela

\begin{tabular}{rlcccc}
\hline No & Tratamiento & Frecuencia & Porcentaje & $\begin{array}{c}\text { Valor para } \\
\text { multiplicar }\end{array}$ & $\begin{array}{c}\text { Valor } \\
\text { escala }\end{array}$ \\
\hline 1 & Negativo (-1) & 178 & 81,7 & -1 & $-81,7$ \\
2 & Neutro (0) & 34 & 15,5 & 0 & 0 \\
3 & Positivo & 8 & 2,8 & +1 & $+2,8$ \\
\hline & Total & 218 & & & \\
& & & & & Fuente: Elaboración propia
\end{tabular}

Para observar en qué valor (positivo o negativo) se encuentra la imagen de Venezuela en los cuatro medios españoles con mayor tiraje y difusión se construyó un "valor escala". Se le asignó el número menos uno (-1) para multiplicar aquellas informaciones negativas, cero (0) para multiplicar las neutras y uno positivo $(+1)$ para las publicaciones positivas. Luego de efectuar dicho procedimiento se restó el valor escala de las informaciones positivas $(+2,8)$ al de las negativas $(-81,7)$, lo cual permitió conocer que el país bolivariano tiene una imagen negativa en un valor escala de $-78,9 \%$. En el gráfico 2 se puede apreciar el lugar que ocupa el tratamiento de Venezuela dentro de la prensa estudiada.

Gráfico 2. Valor escala del tratamiento de Venezuela en la prensa

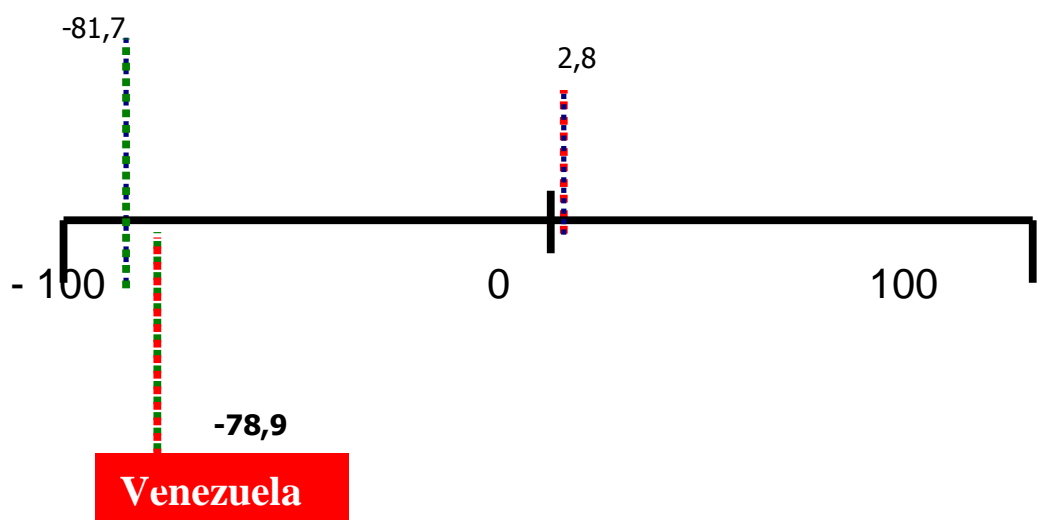

Fuente: Elaboración propia 
Cada unos de los diarios analizados tiene una cobertura similar en su tratamiento en torno a Venezuela. A pesar de pertenecer a grupos y corporaciones distintas, en cada uno de ellos la nación bolivariana tuvo un tratamiento negativo (ver tabla 9).

Tabla 9. Tratamiento y valor escala por diario

\begin{tabular}{|c|c|c|c|c|c|c|}
\hline No & Periódico & Frecuencia & $\begin{array}{c}\text { Positivo \% } \\
(+1)\end{array}$ & $\begin{array}{c}\text { Neutro \% } \\
(0)\end{array}$ & $\begin{array}{c}\text { Negativo \% } \\
(-1)\end{array}$ & $\begin{array}{c}\text { Valor escala } \\
\text { total }^{10}\end{array}$ \\
\hline 1 & El País & 78 & 3 & 23 & 74 & -71 \\
\hline 2 & El Mundo & 49 & 4 & 16 & 80 & -76 \\
\hline 3 & $A B C$ & 57 & 2 & 8 & 90 & -88 \\
\hline 4 & Vanguardia & 34 & 3 & 12 & 85 & -82 \\
\hline
\end{tabular}

Fuente: Elaboración propia

De la tabla anterior se deduce la siguiente información:

a) El medio con mayor publicación negativa es el diario ABC $(90 \%)$, seguido por La Vanguardia (85\%).

b) Los diarios que mostraron mayor neutralidad en el tratamiento de las informaciones fueron El País (23\%) y El Mundo (16\%).

c) Los cuatro diarios mostraron un tratamiento similar para difundir las publicaciones desde una perspectiva positiva: EL País (3\%), El Mundo (4), ABC (2\%) y La Vanguardia (3\%).

A continuación se presenta una comparativa del tratamiento o cobertura que cada diario hizo sobre Venezuela, considerando para ello el valor escala.

Gráfico 3. Comparación de la tendencia noticiosa entre los diarios considerando el valor escala

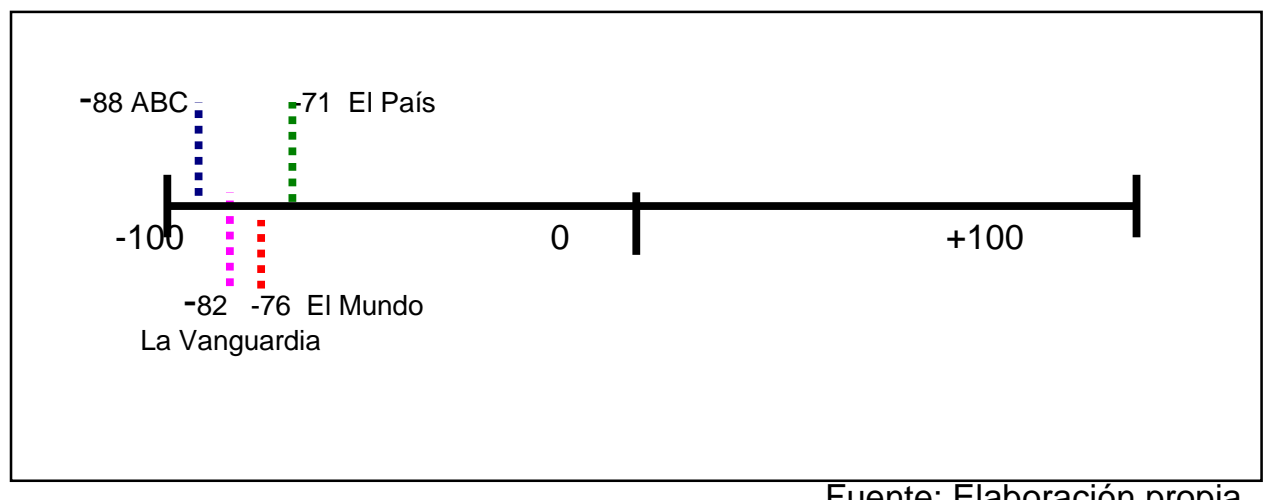

Fuente: Elaboración propia

En dicho gráfico se puede observar que el medio con mayor tendencia negativa es $A B C(-88)$, seguido por La Vanguardia (-82), El Mundo (-76) y El País (-71). 


\subsection{Las fuentes informativas}

La investigación realizada pone en evidencia la escasez de fuentes (emisores de datos del que se sirve el profesional de los medios de comunicación para elaborar el discurso narrativo de su producto informativo) en los trabajos publicados. El 33,5\% de las publicaciones no poseen fuentes que validen o certifiquen los datos suministrados por los redactores y un $22,5 \%$ sólo tienen una fuente como soporte de la información presentada (ver tabla 10).

Tabla 10. Cantidad de fuentes abordadas

\begin{tabular}{llccc}
\hline No & \multicolumn{1}{c}{ Fuentes } & Frecuencia & Porcentaje & $\begin{array}{r}\text { Porcentaje } \\
\text { acumulado }\end{array}$ \\
\hline 1 & Ninguna fuente & 73 & 33,5 & 33,5 \\
2 & Una fuente & 49 & 22,5 & 56 \\
3 & Dos fuentes & 44 & 20,2 & 76,2 \\
4 & De cuatro a cinco fuentes & 26 & 11,9 & 88,1 \\
5 & Tres fuentes & 25 & 11,5 & 99,6 \\
6 & Otras & 1 & 0,4 & 100 \\
\cline { 2 - 5 } & Total & 218 & \multicolumn{2}{c}{ Fuente: Elaboración propia }
\end{tabular}

Esta carencia de fuentes obliga a preguntarse ¿qué periodismo construyen los diarios El País, El Mundo, ABC y La Vanguardia cuando los datos publicados no son corroborados o confirmados?, ¿existe el mismo tratamiento con los demás países de Latinoamérica?, ¿es una política general de los diarios publicar informaciones sin fuentes? Este trabajo no tiene por objetivo responder a estas interrogantes pero sí las descubre para la realización de futuras investigaciones.

A continuación se presenta el ejemplo de una noticia sin fuente, publicada por el diario ABC el 11 de septiembre de 2009 bajo el título: "El bolivariano Chávez se alojará en la "suite royal" a 5.300 euros la noche".

"A Hugo Chávez el petróleo le da para mucho. Sobre todo, para comprar material militar a Rusia por valor de más de 1.500 millones de euros, pero también —en comparación es una menudencia- para pagar 5.300 euros por una «suite royal» en el renovado y lujoso hotel Villamagna de Madrid. El presidente venezolano se alojó en ella cuando llegó la pasada madrugada a la capital de España procedente de Moscú y camino de Caracas, tras una girade casi dos semanas por países a los que considera entre sus grandes aliados: Libia, Argelia, Siria, Irán, Turkmenistán, Bielorrusia y Rusia.

Su escala en Madrid se prolongará hasta media tarde de hoy. Poco antes del mediodía será recibido en la Moncloa, por el presidente del Gobierno, José Luis Rodríguez Zapatero, y, posteriormente, en el Palacio de la Zarzuela, por Su Majestad el Rey, a quien ha insistido en saludar, y con quien da ya por superado el famoso incidente del "¿Por qué no te callas?". No habrá comparecencia conjunta de prensa con Zapatero, que debe viajar a París, pero sin duda, Chávez encontrará la oportunidad para dejar su mensaje en España..." 
De igual forma, al observar la tabla 52 también podemos apreciar que en un $20,2 \%$ de los trabajos publicados se utilizaron dos fuentes al momento de redactar el texto periodístico. El $11,9 \%$ emplearon entre 4 y más fuentes y un 11,5\% usaron tres fuentes. Estos resultados permiten conocer el tratamiento y la profundidad informativa con la cual los periodistas abordan los trabajos que publican con relación a Venezuela.

En el apartado dedicado al análisis de "los géneros periodísticos" se precisa que la noticia es el género que se usa, principalmente, para construir la imagen de Venezuela, pero ¿qué es una noticia sin las fuentes? Más grave aún: ¿qué es una noticia sin fuentes y con un alto contenido de juicios de valor u opinión del redactor (53,9\%)?, ¿dónde queda el deber del periodista de mostrar las diversas facetas de una situación y los distintos actores implicados en el hecho?, pues los principios básicos del periodismo obligan al periodista a triangular fuentes para sustentar una información.

Un periodismo sin fuente no tiene ningún sentido, pues se convierte en una opinión del redactor y esto tiene poca veracidad, fiabilidad y credibilidad informativa. El triangular fuentes y mostrar las diversas caras que intervienen en un hecho es una función irremplazable de los periodistas, pues es la única manera que tienen para demostrar que los hechos presentados en el texto son ciertos.

\subsection{Los autores de las informaciones publicadas}

Dentro de esta categoría se pudo conocer que el $24,3 \%$ de los trabajos publicados no tienen una clara la procedencia de sus autorías. En ese caso El diario El Mundo fue el medio que principalmente hizo uso de esta frecuencia dado que en la autoría de sus trabajos suele colocar "especial para El Mundo".

Los corresponsales se constituyen como la segunda vía por la cual se elaboran los trabajos publicados con un $22,9 \%$. Seguido por los articulista $15,1 \%$ los enviados especiales $10,1 \%$ y los periodistas locales $9,2 \%$ (ver tabla 11).

Tabla 11. Autores de las publicaciones

\begin{tabular}{llccc}
\hline No & \multicolumn{1}{c}{ Autores } & Frecuencia & Porcentaje & $\begin{array}{c}\text { Porcentaje } \\
\text { acumulado }\end{array}$ \\
\hline 1 & Corresponsal & 50 & 22,9 & 22,9 \\
2 & Articulista & 33 & 15,1 & 38 \\
3 & Enviado especial & 22 & 10,1 & 48,1 \\
4 & Periodista local & 20 & 9,2 & 57,3 \\
5 & Sin autor & 18 & 8,3 & 65,6 \\
6 & El propio medio & 16 & 7,3 & 72,9 \\
7 & Agencia de Noticias & 6 & 2,8 & 75,7 \\
8 & Otros & 53 & 24,3 & 100 \\
\hline & Total & 218 & & \\
& & & Fuente: Elaboración propia
\end{tabular}


Partiendo de los resultados anteriores y considerando que el $33,5 \%$ de las publicaciones no poseen fuentes y un $22,5 \%$ sólo tiene una fuente como soporte para argumentar sus trabajos, surge una interrogante ¿para qué los diarios ABC, El País, El Mundo y La Vanguardia cuentan con corresponsales en Venezuela cuando el trabajo que estos periodistas realizan son en su mayoría informaciones escuetas y sin investigación periodística?

De acuerdo con la deontología profesional periodística no se puede hablar de periodismo cuando esa función de comunicar no se con veracidad. No se puede decir que una información es veraz cuando carece de elementos que sustente los hechos que el periodista hace llegar a los receptores como por ejemplo el empleo de las fuentes.

Otro de aspecto que se evidenció en este estudio es que el $8,3 \%$ de las publicaciones no poseen autores o firma nominal por lo que se supone que son redacciones anónimas, lo cual es otro elemento muy negativo dentro del quehacer periodístico que estos diarios hacen sobre Venezuela porque le restan credibilidad a los datos suministrados.

En relación con el uso de las agencias de noticias se pudo conocer que sólo el 2,8\% de las publicaciones tenían como origen una agencia. Si analizamos sólo este tipo de publicaciones encontramos que el $50 \%$ de las informaciones que provenían de una agencia pertenecían a EFE (de procedencia española), un $16,7 \%$ a la Associated Press (AP) (de origen norteamericano) y un $33,3 \%$ eran de una agencia sin identificación.

Por último, hay que indicar que un $7,3 \%$ de los trabajos publicados fueron elaborados por el propio medio, es decir, eran editoriales en los cuales se hablaba de Venezuela ya sea de forma directa o indirecta y cuyo tratamiento fue negativo en un $87 \%$ de los casos. En este sentido, los editoriales evidencian la tendencia de las agendas que imponen los periódicos en estudio, dado son la opinión del medio de comunicación.

\section{Conclusiones}

Tras estudiar el tratamiento informativo que los diarios El País, El Mundo ABC y La Vanguardia efectuaron sobre la República Bolivariana de Venezuela durante el 2009 se llegó a las siguientes conclusiones:

a) En cuanto a la cobertura que cada medio hizo sobre Venezuela se observó que El País $(35,8 \%)$ fue el diario que mayor difusión hizo sobre Venezuela, sus personajes y organizaciones. Seguido del ABC (26,1\%), El Mundo (22,5\%) y La Vanguardia $(15,6 \%)$.

b) Los temas abordados fueron: Situación de Venezuela a causa de su sistema de gobierno, vinculación con el resto de países de Latinoamérica, relación con los países miembros del ALBA, relación con los estados Unidos y relación con España.

En primera instancia, la situación interna de Venezuela ocupó un 31,2\% las informaciones que se difunden sobre dicho país. Son publicaciones tendientes a mostrar a un país estancado en problemas eléctricos, escasez de agua, víctima de la delincuencia, en recesión económica. Con un gobierno que persigue a todos aquellos que tienen a pensar de forma diferente al sistema bolivariano y que limita la libertad de expresión de los ciudadanos. 
El segundo tema abordado fue la relación de Venezuela con los países latinoamericanos (no miembros del ALBA) con un $21,6 \%$. Se da un énfasis a la relación Venezuela-Colombia. Los diarios construyen la imagen de una Venezuela que alberga en su territorio a la FARC y de un gobierno (venezolano) que protege los grupos subversivos y armados.

El tercer tema con mayor difusión fue la "relación de Venezuela con los países miembros del ALBA" el cual alcanzó un 19,7\% dentro de los diarios analizados. Estratégicamente los medios vinculan a Venezuela con los gobiernos de Cuba, Bolivia, Nicaragua y Ecuador. Los relacionan entre sí por sus ideologías izquierdistas y sus políticas antiimperialistas.

Por último, se puede mencionar que los temas en los cuales se relacionó a Venezuela con los Estados Unidos de Norteamérica y con España tuvieron poca cobertura con respecto a los temas anteriores con un $7,8 \%$ y un $6,4 \%$ respectivamente.

En referencia a los Estados Unidos se presenta a un Presidente Obama que busca mediar y mejorar las relaciones con los países latinoamericanos. Mientras que por su parte el gobierno venezolano aparece con una política ofensiva contra la nación norteamericana.

Al referirse a España los medios abordan las relaciones comerciales entre ambos países y presentan a una Venezuela sin garantía jurídica ni económica para los empresarios. No obstante, existe una disparidad en el discurso de los trabajos publicados, pues a pesar de expresar que Venezuela es una nación peligrosa por las nacionalizaciones implementadas por el Estado venezolano, también se observa que los vínculos económicos entre España y Venezuela se afianza tal es el caso de las empresas Repsol y Telefónica.

c) En relación a los géneros periodísticos se precisó que hay un predominio de la noticia con un $58,7 \%$. A este porcentaje le siguen los artículos de opinión (15,6\%). Es fundamental resaltar el tratamiento que hacen sobre las informaciones publicadas, pues en las noticias difundidas los redactores emiten opiniones $(53,9 \%)$ en el desarrollo del tema, lo cual no es propio de este género periodístico sino de los artículos de opinión.

De acuerdo con los principios básicos de la profesión periodística e incluso el propio manual de estilo del diario El País, los redactores no pueden elaborar noticias emitiendo opiniones o juicios de valor, pues esto rompe con la concepción de dicho género periodístico, dado que en la noticia el periodista sólo debe limitarse a presentar los hechos y a mostrar los diversos actores que intervienen en el mismo.

d) En torno a las fuentes periodísticas los trabajos publicados demuestran poca profundidad y abordaje periodístico, pues en un 33,5\% de las publicaciones no se emplearon fuentes. Además existe un $22,5 \%$ que sólo tenían una fuente para sustentar los datos que publicaron. Es decir, un $56 \%$ tienen entre cero y una fuente.

En ese sentido, el tratamiento periodístico que los redactores hacen sobre las informaciones publicadas demuestra un periodismo escueto y superficial que incumple con los principios básicos de la profesión de triangular las fuentes y de mostrar los diversos actores que intervienen en un suceso.

Si analizamos detalladamente las publicaciones que son noticias vemos de ese $58,7 \%$ existe un $31,6 \%$ de los textos en los cuales los periodistas emiten juicios de valores u opiniones, lo cual rompe con la concepción básica de una noticia. Si a dicho porcentaje le sumamos que el $56 \%$ de 
las informaciones poseen entre cero y una fuente encontramos que el periodismo que se publica en dichos diarios tiene una tendencia a ser de "artículos de opinión".

Al añadir ese $31,6 \%$ de las noticias donde se opina al 15,6\% que representan los artículos de opinión encontramos que existe un $47,2 \%$ de los trabajos publicados tendientes a omitir opiniones sobre los hechos divulgados.

e) El tratamiento de la imagen de Venezuela dentro de las publicaciones efectuadas fue negativo en un $81,7 \%$. Las informaciones positivas sólo representan un $2,8 \%$; mientras que las neutras tienen un $15,5 \%$. Con miras a conocer el nivel de validez de estos porcentajes se aplicó un Intercoder Reliability $(I C R)$ al 25 de las informaciones estudiadas y se obtuvo un nivel de coincidencia en las codificaciones de un $80 \%$.

Los diarios con mayor tratamiento negativo fueron ABC (90\%) y la Vanguardia (85\%). Mientras que El Mundo fue el medio que mayor publicación positiva realizó con un 4\%.

\section{Bibliografía}

ALONSO, Rodrigo, (1993) Imagen de marca. Editorial Acento Gráfico. Madrid. España.

ALVAREZ, Tomás y CABALLERO, Mercedes (1997). Vendedores de imagen. Los retos de los nuevos gabinetes de comunicación. Editorial Paidós. Barcelona. España.

BODAS, José y GRAGOEVIC, Adriana (1994). El mundo Árabe y su imagen en los medios. Comunica. Madrid. España.

BUSTAMANTE, Enrique (1982). Los amos de la información en España. Akal Universitaria. Madrid. España

CHOI, Jinbong (2006). "Framing the National Image of North Korea in the U.S. News Media". Conference Papers -- International Communication Association; Annual Meeting, p1-32, 32p

CORBU, Nicoleta (2009). "Brand Image. A cross-cultural perspective". Journal of Media Research; Issue 5, p72-88, 17p, 10 Charts

COSTA, Johan (2004). La imagen de marca. Un fenómeno social. Editorial Paidós. Barcelona. España.

DAY, J.; SKIDMORE, S.; and KOLLER, T. (2002). "Image selection in destination positioning: $A$ new approach”. Journal of Vacation Marketing, 8(2), 177-186.

DEL REY MORATÓ, Javier (1997). Los juegos de los políticos. Teoría general de la información y comunicación política. Editorial Tecnos, S.A. Madrid. España.

GRABER, Doris (1995). Los medios de comunicación y la política americana. Los medios como gobierno en la sombra. EN: Comunicación y política. Compilado por MUÑOZ, Alejandro y ROSPIR, Juan. Editorial Universitas, S.A. Madrid. España. 
GONZALEZ, Mario (2008). Dictadura mediática globalizada. Etapa superior al imperialismo yanqui. Fondo editorial IPASME. Caracas-Venezuela.

IGARTUA, Juan y HUMANES, María (2004). "Imágenes de Latinoamérica en la prensa española. Una aproximación empírica desde la teoría del encuadre”. Revista Comunicación y Sociedad. Vol. XVII. Núm. 1. pág. g47-75.

IND, Nicholas (1992). La imagen corporativa. Estrategias para desarrollar programas de identidad eficaces. Editorial Díaz de Santos, S.A. Madrid. España.

KRIPPENDORFF, Klaus (1990). Metodología de análisis de contenido. Edit. Paidós. Barcelona.

LOPES, Elaine (2005). La Imagen de Marca País de España en Brasil. Tesis Doctoral Universidad de Barcelona. Barcelona. España.

LOPEZ, Eduardo (1990) La Imagen del nacionalismo vasco y de la violencia política en el País Vasco en la prensa americana (Estados Unidos Gasteiz: Eusko jaurlaritzaren argitalpen zerbitzu nagusia $=$ Servicio central de publicaciones del Gobierno Vasco. España.

MACKAY, K. J. \& FESENMAIER, D. R. (1997) "Pictorial element of destination in image formation. Annals of Tourism Research", 24(3), 537-565

MATTELAR, Armand (1978). La comunicación masiva en el proceso de liberación. Siglo veintiuno editores, S.A. Madrid. España.

MARTINEZ, Pilar y DIAZ, Mario (2003). La Imagen de España y Francia en los medios de comunicación. Colección Extremos. Extremadura. España.

MCCARTNEY, Glenn; BUTLER, Richard y BENNETT Marion (2008). "A Strategic Use of the Communication Mix in the Destination Image-Formation Process". Journal of Travel Research Vol. 47, No. 2, p.p183-196 originally published online Jul 22, 2008. DOI: 10.1177/0047287508321201. Copyright SAGE Publications.

NOYA Javier, CHEN Li, GONZALEZ Ildefonso, RODRIGUEZ, Beatriz y ROMERO, Héctor (2007). La imagen de España en China. Real Instituto Elcano de Estudios Internacionales Estratégicos. Madrid- España.

ORTIGUEIRA, Manuel (2000). Marketing público: imágenes de España y de otros países en un marco internacional. Editorial. Consellería de Economía e Facenda. Galicia. España

PINEDA, Migdalia (2004). La Ciencia de la Comunicación a la luz del siglo XXI. Ediluz. Maracaibo- Venezuela.

SUMAN, Lee (2003). "Image of nations: Coverage of foreign nations in the Korean media". Conference Papers -- International Communication Association; Annual Meeting, San Diego, CA, p1-24, 22p, 1 Diagram, 2 Charts 
TASCI, Asli D. A. y KOZAK, Metin, (2006). "Destination brands vs destination images: Do we know what we mean?" Journal of Vacation Marketing, Vol. 12, No. 4, 299-317. DOI: 10.1177/1356766706067603. Copyright SAGE Publications.

TELLERÍA, María (2005). Los medios de comunicación al servicio del poder. La influencia mediática en la sociedad global. Erasmus Ediciones. Barcelona. España.

VILLAFAÑE, Justo (1992). "La gestión estratégica de la imagen corporativa. En. La imagen corporativa". A5. Revista de Comunicación Audiovisual y Publicitaria. Número 1. Septiembrediciembre. Madrid. España.

\section{Notas.}

\footnotetext{
${ }_{1}^{1}$ Por ser pagos

${ }^{2}$ Aquellos trabajos periódicos que abordan como tema central un hecho suscitado en Venezuela o en el cual se haga referencia a sus personajes, dirigentes, instituciones y organizaciones.

${ }^{3}$ Aquellos trabajos periodísticos que aunque no aborde un hecho de Venezuela la relacionan o vinculan con el mismo. Por ejemplo: puede existir una noticia que hable sobre la situación en Bolivia, pero en el desarrollo de la noticia se habla sobre Venezuela o sobre sus instituciones, personajes $u$ organizaciones.

${ }^{4}$ Edición aleatoria para el inicio del salto sistemático

${ }^{5}$ Fecha del diario a analizar

${ }^{6}$ Informaciones relacionas con Venezuela

${ }^{7}$ El 18,14\% de los productos exportados por España van a Brasil. Luego viene Argentina con 12,35\%. Así lo reveló el estudio elaborado por el Centro de Estudios Latinoamericanos presentado en diciembre de 2007.

${ }^{8}$ De acuerdo con el informe anual elaborado por la Oficina de Droga y Delito de la Organización de las Naciones Unidas en el 2008 Colombia es el mayor país de cultivo del arbusto de coca, con 81.000 hectáreas.

${ }^{9}$ El $25 \%$ de las informaciones que integran la muestra fueron codificadas por otros individuos (un ciudadano de Costa Rica, una venezolana, un español y dos dominicanos).

${ }^{10}$ Se multiplicó por más uno $(+1)$ el porcentaje positivo, por cero $(0)$ el valor neutro y por menos uno $(-1)$ el porcentaje negativo. Luego se hizo una sustracción del valor escala positivo al negativo y se obtuvo el valor escala total del tratamiento por cada diario.
} 